\title{
Lignocaine Therapy after Acute Myocardial Infarction
}

\author{
M. P. CHOPRA,* M.B., B.S.; R. W. PORTAL, $\dagger$ M.D., M.R.C.P. ; CLIVE P. ABER, $\dagger$ M.D., B.SC., M.R.C.P.
}

Brit. med. F., 1969, 1, 213-216

Summary: Thirty-five patients with ventricular dysrhythmias and seven with other dysrhythmias after acute myocardial infarction were treated with intravenous lignocaine.

Satisfactory initial suppression of ventricular ectopic beats was achieved in $27(82 \%)$ of 33 patients after either a 50-mg. bolus or a 50-mg. bolus followed by a $100-\mathrm{mg}$. bolus of intravenous $2 \%$ lignocaine. Continuous suppression of ventricular ectopic beats was accomplished in 21 $(78 \%)$ of these 27 patients by continuous intravenous lignocaine infusions of 1 to $2 \mathrm{mg}$. per minute. Recurrence of ventricular ectopic beats occurred in four patients despite lignocaine infusion rates of up to $6 \mathrm{mg}$. per minute. Six patients with ventricular ectopic beats developed ventricular fibrillation despite satisfactory initial suppression of their dysrhythmia by lignocaine. In three of them ventricular fibrillation supervened while they were receiving a lignocaine infusion and two subsequently died. Unheralded ventricular fibrillation occurred in three other patients between four and seven days after completing the full course of lignocaine therapy.

Toxic effects of lignocaine were minimal in patients receiving 1 to $2 \mathrm{mg}$. per minute.

\section{Introduction}

Lignocaine was first shown to have antidysrhythmic properties by Southworth et al. (1950). Subsequently it was used successfully in the management of ventricular dysrhythmias during and after cardiac surgery (Carden and Steinhaus, 1956 ; Likoff, 1959 ; Harrison et al., 1963). More recently it has been proposed as the drug of choice for the control of ventricular dysrhythmias after myocardial infarction (Gianelly et al., 1967 ; Lown et al., 1967 ; Jewitt et al., 1968 ; Spracklen et al., 1968). Lown et al. (1967) did not observe any instance of primary ventricular fibrillation in 130 patients with acute myocardial infarction who received lignocaine therapy for ventricular ectopic beats. The drug is now widely accepted as an effective antidysrhythmic agent.

We here report our experience of its use in dysrhythmias after acute myocardial infarction.

\section{Patients and Methods}

The patients were treated in a nine-bedded cardiac monitoring unit the organization of which has been described elsewhere (Aber et al., 1969). Forty-two patients (36 males and 6 females) were studied. Their ages ranged from 42 to 69 years. All were admitted within 48 hours of the initial symptoms of their current illness. The diagnosis of acute myocardial infarction was based on the E.C.G. criteria of the World Health Organization (1959) and/or raised serum enzymes (aspartate aminotransferase and $\alpha$-hydroxybutyric dehydrogenase). On admission each patient was given a Peel index coding (Peel et al., 1962) and grouped according to the Ministry of Health's grading of clinical severity (Aber et al., 1969).

* Research Assistant.

+ Consultant Physician.

Department of Cardiology, Kingston General Hospital, Hull
Continuous individual oscilloscopic E.C.G. monitoring was maintained during the patient's stay in the unit (Cardiorater, Cardiac Recorders), and all patients received humidified oxygen at 4 litres a minute by nasal catheters for 72 hours. E.C.G. records were obtained daily or as required.

Criteria for Selection for Lignocaine Therapy.-Patients received lignocaine therapy if they developed any form of ectopic beats (atrial, nodal, or ventricular) with one or more of the following characteristics (Lown et al., 1967): (a) the occurrence of ectopic beats at a rate of more than $5 /$ minute ; $(b)$ the occurrence of ectopic beats during the "vulnerable period" of the preceding beat-that is, a $\mathrm{Q}-\mathrm{R}^{\prime} / \mathrm{Q}-\mathrm{T}$ ratio of less than 0.85 , where $Q-R^{\prime}$ is the interval between the onset of normal $Q R S$ complex preceding the ectopic beat and the discharge of the ectopic beat, and Q-T is the duration of the normal QRST complex; $(c)$ the occurrence of two or more consecutive ectopic beats ; and (d) multiform configuration of ectopic beats.

Lignocaine Administration.-An initial rapid intravenous injection of $50 \mathrm{mg}$. of $2 \%$ lignocaine hydrochloride was administered. If the ectopic beats were still present five minutes after this injection a further intravenous injection of $100 \mathrm{mg}$. of $2 \%$ lignocaine was given. These injections will henceforth be referred to as the lignocaine boluses. If the ectopic beats were suppressed by either the first or the second bolus a continuous intravenous drip infusion of $1 \mathrm{mg}$./minute was begun. If during this continuous infusion the ectopic beats recurred the rate was increased to $2 \mathrm{mg}$./minute, or if necessary to a higher rate. A $0.2 \%$ lignocaine solution in $5 \%$ dextrose was used in patients without heart failure and a $0.4 \%$ solution in patients with failure. The infusion was continued for 24 hours. The rate was now halved for two hours and then discontinued. If ectopic beats recurred later, a second course of lignocaine therapy was given.

E.C.G. Recording.-Serial E.C.G. strips were recorded by Mini-Writer MK II (Cardiac Recorders) at the following times: before starting the lignocaine therapy; during the intravenous lignocaine injection and for one minute afterwards-subsequently, 10-second strips were recorded at one-minute intervals for the next five minutes; during the continuous intravenous lignocaine infusion 10-second strips were recorded every 15 minutes for the first hour and then hourly for the remainder of the infusion period; while tapering off the infusion a 10seconds record was made every 15 minutes for two hours; and after completion of lignocaine infusion a 10 -seconds record was made every 30 minutes for 12 hours. These permanent records were supplemented by frequent inspection of the oscilloscopic tracing by medical and nursing staff.

Arterial blood gas and acid-base measurements were made on 21 patients before starting lignocaine therapy. In nine these determinations were repeated after suppression of the ectopic beats and immediately after termination of the lignocaine infusion. Blood samples were taken from the brachial artery and analysed immediately by an Instrumentation Laboratory $\mathrm{pH}$ blood gas analyser (model 113-S1). During treatment no attempt was made to correct any observed metabolic disturbances.

\section{Results}

Lignocaine therapy was used in a total of 42 patients (Table I), 38 of whom received treatment for ectopic beats (Table II). 
In addition the drug was given to two patients with nodal tachycardia and to two who had been restored to sinus rhythm by D.C. countershock for ventricular fibrillation. In 28 patients the indication for the drug arose within 24 hours of the infarct, in 11 between 24 and 48 hours, and in 3 between 7 and 10 days after infarction.

TABLE I.-Response to Lignocaine Therapy in 42 Patients after Acute Myocardial Infarction

\begin{tabular}{|c|c|c|c|c|}
\hline \multirow{3}{*}{$\begin{array}{c}\text { Type of } \\
\text { Dysrhythmia }\end{array}$} & \multirow{3}{*}{$\begin{array}{c}\text { No. of } \\
\text { Patients }\end{array}$} & \multicolumn{3}{|c|}{ Response } \\
\hline & & \multicolumn{2}{|c|}{ Suppression } & \multirow{2}{*}{$\begin{array}{c}\text { No } \\
\text { Suppression }\end{array}$} \\
\hline & & $\begin{array}{l}\text { 50-mg. } \\
\text { Dose }\end{array}$ & $\begin{array}{c}\text { 100-mg. } \\
\text { Dose }\end{array}$ & \\
\hline $\begin{array}{ll}\text { Ventricular ectopic beats } & \ldots \\
\text { Atrial ectopic beats } & \ldots \\
\text { Nodal ectopic beats .. } & \ldots \\
\text { Nodal tachycardia } & \ldots \\
\text { Post-ventricular fibrillation } & .\end{array}$ & $\begin{array}{r}33 \\
3 \\
2 \\
2 \\
2\end{array}$ & $\begin{array}{l}19 \\
1+2 * \\
\text { Ne recu } \\
\text { ventri } \\
\text { lation }\end{array}$ & $\begin{array}{l}\frac{8}{2} \\
\text { nce } \\
\text { ar of } \\
\text { patibril- }\end{array}$ & $\begin{array}{c}6 \\
\quad \text { None } \\
\text { None } \\
2 \\
\text { Recurrence of } \\
\text { ventricular } \\
\text { fibrillation } \\
\text { (1 patient) }\end{array}$ \\
\hline
\end{tabular}

* Ectopic beats had disappeared before 50 -mg. bolus of lignocaine was given.

TABLE II.-Indications for Lignocaine Therapy in 38 Patients with Ectopic Beats after Acute Myocardial Infarction

\begin{tabular}{c|c|c|c}
\hline Indications & $\begin{array}{c}\text { Ventricular } \\
\text { (33 Patients) }\end{array}$ & $\begin{array}{c}\text { Atrial } \\
\text { (3 Patients) }\end{array}$ & $\begin{array}{c}\text { Nodal } \\
\text { (2 Patients) }\end{array}$ \\
\hline $\begin{array}{c}\text { a } \\
\mathrm{b} \\
\mathrm{d} \\
\text { More than one }\end{array}$ & $\frac{21}{1}$ & $\underline{3}$ & $\underline{2}$ \\
\hline
\end{tabular}

For indications $a, b, c$, and $d$, see text.

\section{Ventricular Ectopic Beats}

Ventricular ectopic beats occurred in 33 patients (Tables I and III). Patients with high Peel indices appeared to have a greater chance of developing frequent unifocal ventricular ectopic beats than those with Peel indices below 12. However, there was no obvious relation between any form of ventricular ectopic beat and the clinical grading of severity (M.O.H. criteria) (Table IV). The number of patients is too small for statistical analysis.

TABLE III.-Response to Lignocaine Therapy in 33 Patients with TABLE IIt--Response to Lignocaine Therapy in 33 Patients with
Ventricular Ectopic Beats after Acute Myocardial Infarction

\begin{tabular}{c|c|c|c|c}
\multicolumn{1}{c}{$\begin{array}{c}\text { Indications for } \\
\text { Lignocaine } \\
\text { Therapy }\end{array}$} & $\begin{array}{c}\text { No. of } \\
\text { Patients }\end{array}$ & \multicolumn{3}{|c}{ Response } \\
\cline { 3 - 4 } & & \multicolumn{2}{|c}{ Suppression } & $\begin{array}{c}\text { No } \\
\text { Suppression }\end{array}$ \\
\hline a & 21 & 13 & 3 & 5 \\
$\mathrm{~d}$ & 1 & 1 & 0 & 0 \\
ac & 4 & 3 & 3 & 0 \\
ad & 5 & 2 & 1 & 0 \\
abd & 1 & 0 & 1 & 0 \\
\hline cd & 1 & 0 & 8 & 6 \\
\hline Total & 33 & 19 &
\end{tabular}

TABLE IV.-Relation Between Types of Ventricular Ectopic Beats and Clinical Grading of Severity (M.O.H.) and Peel Index in 33 Patients after Acute Myocardial Infarction

\begin{tabular}{|c|c|c|c|c|c|c|c|c|}
\hline \multirow[b]{2}{*}{ 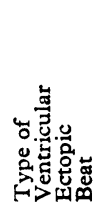 } & \multicolumn{4}{|c|}{ Clinical Grading (M.O.H.) } & \multicolumn{4}{|c|}{ Peel Index } \\
\hline & 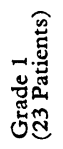 & 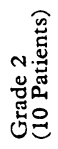 & 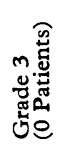 & 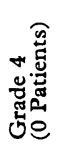 & 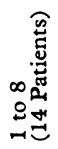 & 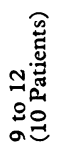 & 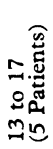 & 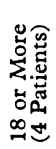 \\
\hline $\begin{array}{r}\mathrm{a} \\
\mathrm{d} \\
\mathrm{ac} \\
\mathrm{ad} \\
\mathrm{abd} \\
\mathrm{cd}\end{array}$ & $\begin{array}{r}14 \\
1 \\
3 \\
3 \\
1 \\
1\end{array}$ & $\begin{array}{l}7 \\
\frac{7}{2} \\
-\end{array}$ & $\begin{array}{l}E \\
E \\
E\end{array}$ & $\begin{array}{l}= \\
= \\
=\end{array}$ & $\begin{array}{l}6 \\
1 \\
3 \\
2 \\
1 \\
1\end{array}$ & $\begin{array}{l}7 \\
1 \\
2 \\
-\end{array}$ & $\begin{array}{l}5 \\
= \\
=\end{array}$ & $\frac{3}{1}$ \\
\hline
\end{tabular}

The criteria for lignocaine administration in this group and the response to treatment are summarized in Table III. Suppression of ectopic beats by the initial boluses was observed in 27 patients (82\%). In 19 patients (57\%) a 50-mg. bolus of lignocaine was effective, whereas eight $(24 \%)$ required a further 100-mg. bolus.

The initial boluses failed to suppress ectopic beats in six patients, of whom five had unifocal ectopic beats and one had unifocal and consecutive ectopic beats (Table III).

Continued suppression for 24 hours was achieved in 22 patients, of whom 13 required an infusion rate of $1 \mathrm{mg} . /$ minute, 8 a rate of $2 \mathrm{mg}$./minute, and 1 a rate of $3 \mathrm{mg}$./minute.

In four patients the infusion failed to prevent the recurrence of ventricular dysrhythmias-three developed ectopic beats followed by ventricular fibrillation while on infusion rates of 2 to $4 \mathrm{mg}$./minute, and one developed ventricular fibrillation without the observation of preceding ectopic beats (infusion rate $1 \mathrm{mg}$./minute). In one patient whose ectopic beats were successfully suppressed by an infusion of $2 \mathrm{mg}$./minute sideeffects developed, and it became necessary to discontinue the infusion. Successful suppression of ectopic beats appeared to be unrelated to the characteristics of the beats (see Table III). The initial dose of lignocaine required to suppress ectopic beats was not related to the clinical state of the patients on admission or to their Peel indices (Table V).

TABLE V.-Relation Between Response to Lignocaine Dose (as Bolus) and Clinical Grading of Severity (M.O.H.) and Peel Index in 33 Patients with Ventricular Ectopic Beats after Acute Myocardial $\backslash$ Infarction

\begin{tabular}{|c|c|c|c|c|c|c|c|c|}
\hline \multirow[b]{2}{*}{ Response } & \multicolumn{4}{|c|}{ Clinical Grading (M.O.H.) } & \multicolumn{4}{|c|}{ Peel Index } \\
\hline & 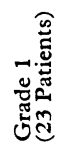 & 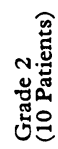 & 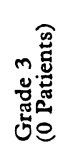 & 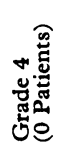 & 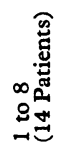 & 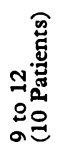 & 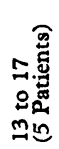 & 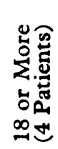 \\
\hline $\begin{array}{l}\text { Suppression to } \\
50-\mathrm{mg} \text {. dose }\end{array}$ & 10 & 9 & - & - & 6 & 7 & 4 & 2 \\
\hline $\begin{array}{l}\text { Suppression to } \\
100 \text {-mg. dose }\end{array}$ & 7 & 1 & - & - & 5 & - & 1 & 2 \\
\hline $\begin{array}{l}\text { No suppres- } \\
\text { sion } \quad .\end{array}$ & 6 & - & - & - & 3 & 3 & 一 & 一 \\
\hline
\end{tabular}

No relation was observed between the time of onset of ectopic beats after infarction and either the nature of the ectopic beats or the response to treatment.

\section{Other Dysrhythmias}

Atrial Ectopic Beats.-These were observed in three patients. In two, however, the ectopic beats had disappeared before lignocaine therapy was begun, and they never returned. The third patient responded to the $50-\mathrm{mg}$. bolus of lignocaine but required a continuous infusion at a rate of $2 \mathrm{mg}$./minute to maintain suppression. He developed atrial flutter-fibrillation while the lignocaine infusion was being tailed off.

Nodal Ectopic Beats.-These occurred in two patients. Both required consecutive $50-\mathrm{mg}$. and $100-\mathrm{mg}$. boluses of lignocaine for suppression. Satisfactory suppression for 24 hours was obtained by continuous infusion of $1 \mathrm{mg}$./minute in one patient and $2.5 \mathrm{mg}$./minute in the other.

Nodal Tachycardia.-In two patients nodal tachycardia was uninfluenced by consecutive $50-\mathrm{mg}$. and $100-\mathrm{mg}$. boluses of lignocaine.

Post-ventricular Fibrillation.-Two patients were given lignocaine therapy as a prophylactic measure following D.C. countershock for ventricular fibrillation. Despite an infusion rate of up to $2.5 \mathrm{mg}$./minute recurrent and ultimately fatal ventricular fibrillation occurred in one of them. No further ventricular dysrhythmia was observed in the other patient. 


\section{Repeated Lignocaine Therapy}

Three patients were given a second course of lignocaine therapy-two for recurrence of frequent ventricular and one for frequent nodal ectopic beats. Satisfactory suppression was achieved in all of them.

\section{Arterial Blood Gases and pH Analyses}

The individual changes in blood gases and $\mathrm{pH}$ are shown in Table VI. Serial blood analyses showed no definite pattern. The response to lignocaine was not related to the patient's acidbase status before the administration of the drug and successful suppression of ectopic beats was sometimes achieved in the face of marked acidosis.

TABle VI.-Changes in Arterial Oxygen and Carbon Dioxide Tensions and $\mathrm{pH}$ in 21 Patients who Received Lignocaine Therapy After Acute Myocardial Infarction

\begin{tabular}{|c|c|c|c|c|c|c|}
\hline \multirow{2}{*}{$\begin{array}{l}\text { Case } \\
\text { No. }\end{array}$} & \multirow{2}{*}{$\underset{(\mathrm{mm} . \mathrm{Hg})}{\mathrm{PaO}_{2}}$} & \multirow{2}{*}{$\underset{(\mathrm{mm} . \mathrm{Hg})}{\mathrm{PaCO}_{2}}$} & \multirow[b]{2}{*}{$p \mathrm{H}$} & \multirow{2}{*}{$\begin{array}{c}\text { Base } \\
\text { Excess/ } \\
\text { Deficit }\end{array}$} & \multicolumn{2}{|c|}{ Suppression } \\
\hline & & & & & $\begin{array}{l}\text { 50-mg. } \\
\text { Dose }\end{array}$ & $\begin{array}{l}100 \text {-mg. } \\
\text { Dose }\end{array}$ \\
\hline 1$\}$ & $\begin{array}{ll}\text { a } & 50 \\
\text { b } & 58 \\
\text { c } & 55\end{array}$ & $\begin{array}{l}27 \\
25 \cdot 5 \\
37\end{array}$ & $\begin{array}{l}7 \cdot 4 \\
7 \cdot 46 \\
7 \cdot 57\end{array}$ & $\begin{array}{r}-7 \\
-4 \\
+11\end{array}$ & Yes & \\
\hline 2\{ & $\begin{array}{l}\text { a } 51 \\
\text { b } 82^{*} \\
\text { c } 80^{*}\end{array}$ & $\begin{array}{l}41 \\
27 \\
32 \cdot 5\end{array}$ & $\begin{array}{l}7 \cdot 25 \\
7 \cdot 14 \\
7 \cdot 4\end{array}$ & $\begin{array}{c}-8.5 \\
-18 \\
-3.5\end{array}$ & & Yes \\
\hline 3\{ & $\begin{array}{l}\text { a } 52 \\
\text { b } 86^{*} \\
\text { c } 75^{*}\end{array}$ & $\begin{array}{l}57 \cdot 5 \\
50 \cdot 5 \\
36 \cdot 0\end{array}$ & $\begin{array}{l}7 \cdot 15 \\
7 \cdot 25 \\
7 \cdot 4\end{array}$ & $\begin{array}{l}-10 \\
-6 \\
-2\end{array}$ & Yes & \\
\hline 45 & $\begin{array}{ll}\text { a } & 68 \\
\text { b } & 85^{*} \\
\text { c } & 68^{*}\end{array}$ & $\begin{array}{l}36 \\
32 \\
30 \cdot 5\end{array}$ & $\begin{array}{l}7 \cdot 35 \\
7 \cdot 33 \\
7 \cdot 42\end{array}$ & $\begin{array}{l}-5 \\
-8 \\
-3 \cdot 5\end{array}$ & Yes & \\
\hline 5$\}$ & $\begin{array}{ll}\text { a } & 160^{*} \\
\text { b } & 118^{*} \\
\text { c } & 110^{*}\end{array}$ & $\begin{array}{l}45 \\
27 \\
36\end{array}$ & $\begin{array}{l}7 \cdot 33 \\
7 \cdot 22 \\
7 \cdot 38\end{array}$ & $\begin{array}{c}-2 \\
-11 \cdot 5 \\
-3\end{array}$ & t & \\
\hline $6 \leqslant$ & $\begin{array}{ll}\text { a } & 145^{*} \\
\text { b } & 142^{*} \\
\text { c } 121^{*}\end{array}$ & $\begin{array}{l}40 \\
47 \\
42\end{array}$ & $\begin{array}{l}7 \cdot 31 \\
7 \cdot 23 \\
7 \cdot 38\end{array}$ & $\begin{array}{r}-6 \\
-8 \\
0\end{array}$ & No & Yes \\
\hline 7\{ & $\begin{array}{ll}\text { a } & 71^{*} \\
\text { b } & 71^{*} \\
\text { c } & 65^{*}\end{array}$ & $\begin{array}{l}36 \\
35 \\
29\end{array}$ & $\begin{array}{l}7 \cdot 45 \\
7 \cdot 46 \\
7 \cdot 46\end{array}$ & $\begin{array}{l}+1.5 \\
+1.5 \\
-1.5\end{array}$ & No & Yes \\
\hline 8$\}$ & $\begin{array}{ll}\text { a } & 102 * \\
\text { b } & 102 * \\
\text { c } 122^{*}\end{array}$ & $\begin{array}{l}42 \\
29 \\
26\end{array}$ & $\begin{array}{l}7 \cdot 41 \\
7 \cdot 37 \\
7 \cdot 42\end{array}$ & $\begin{array}{l}+2 \\
-7 \cdot 5 \\
-6\end{array}$ & No & Yes \\
\hline 9\{ & $\begin{array}{ll}\text { a } & 160^{*} \\
\text { b } & 160^{*} \\
\text { c } & 78^{*}\end{array}$ & $\begin{array}{l}40 \\
32 \cdot 5 \\
38\end{array}$ & $\begin{array}{l}7 \cdot 34 \\
7 \cdot 38 \\
7 \cdot 36\end{array}$ & $\begin{array}{l}-2 \\
-5 \\
-3\end{array}$ & Yes & \\
\hline $\begin{array}{l}10 \\
11 \\
12\end{array}$ & $\begin{array}{lc}\text { a } & 138^{*} \\
\text { a } & 60 \\
\text { a } & 70\end{array}$ & $\begin{array}{l}36 \\
36 \\
50\end{array}$ & $\begin{array}{l}7.33 \\
7 \cdot 4 \\
7 \cdot 45\end{array}$ & $\begin{array}{l}-6 \\
-2 \\
+9\end{array}$ & $\begin{array}{l}\text { Noo } \\
\text { Yes }\end{array}$ & Yes \\
\hline 13 & $\begin{array}{ll}\text { a } & 95^{*} \\
\text { a } & 52\end{array}$ & $\begin{array}{l}23.5 \\
34\end{array}$ & $\begin{array}{l}7.49 \\
7.41\end{array}$ & $\begin{array}{l}-2 \\
-3\end{array}$ & $\begin{array}{l}\text { No } \\
\text { No }\end{array}$ & $\begin{array}{l}\text { No } \\
\text { No }\end{array}$ \\
\hline $\begin{array}{l}15 \\
16\end{array}$ & $\begin{array}{ll}\text { a } & 60 \\
\text { a } & 78 \ldots\end{array}$ & $\begin{array}{l}50 \\
40\end{array}$ & $\begin{array}{l}7 \cdot 45 \\
7 \cdot 38\end{array}$ & $\begin{array}{l}+9 \\
-1\end{array}$ & $\begin{array}{l}\text { Yes } \\
\text { Yes }\end{array}$ & \\
\hline $\begin{array}{l}17 \\
18\end{array}$ & $\begin{array}{c}\text { a } 140^{\circ} \\
\text { a } 55\end{array}$ & $\begin{array}{l}42 \\
18\end{array}$ & $\begin{array}{l}7.36 \\
7.46\end{array}$ & $\begin{array}{l}-1 \\
-9\end{array}$ & $\begin{array}{l}\text { No } \\
\text { Yes }\end{array}$ & No \\
\hline $\begin{array}{l}19 \\
20\end{array}$ & $\begin{array}{ll}\text { a } & 70 \\
\text { a } & 59\end{array}$ & $\begin{array}{l}16 \\
36 \cdot 5\end{array}$ & $\begin{array}{l}7.35 \\
7.41\end{array}$ & $\begin{array}{r}-15 \\
-2\end{array}$ & $\begin{array}{l}\text { No } \\
\text { No }\end{array}$ & $\begin{array}{l}\text { No } \\
\text { No }\end{array}$ \\
\hline 21 & a $130^{*}$ & 30 & $7 \cdot 28$ & $-11 \cdot 5$ & Yes & Yes \\
\hline
\end{tabular}

a = Pre-lignocaine therapy.

= Immediately after suppression of ectopic beats

= Immediately after termination of lignocaine infusion.

+ E topic beats had disappeared before $50-\mathrm{mg}$. bolus of lignocaine was given.

\section{Side-effects}

Side-effects were observed in five patients and necessitated discontinuation of treatment in two. No side-effects were produced by the $50-\mathrm{mg}$. bolus of lignocaine. After the $100-\mathrm{mg}$. bolus two patients immediately complained of "dizziness and ringing in the ears." These effects disappeared within five minutes. Two patients became "dizzy" while on continuous infusions at $2 \mathrm{mg}$./minute, and one of them also became hypotensive. In one patient with recurrent attacks of ventricular fibrillation the infusion was progressively increased to a rate of $6 \mathrm{mg}$./minute. He became unconscious with twitching of the limbs, a sucking reflex, and hypotension. These toxic effects soon disappeared on discontinuing the infusion.

\section{Deaths}

Ten of the 42 patients treated with lignocaine died in hospital. Three died while receiving lignocaine and seven at various intervals after the treatment. Details are shown in Table VII.

TABLE VII.-Analyses of Deaths in Lignocaine-treated Cases after Acute

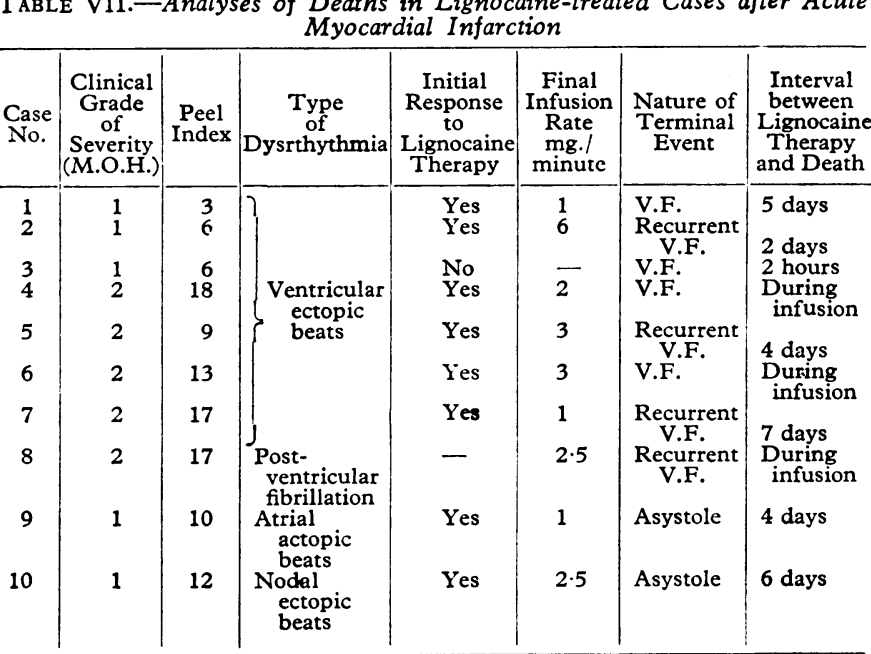
V.F. $=$ Ventricular fibrillation.

Of the seven deaths in the ventricular ectopic group four were in heart failure on admission and three also scored 13 or more on the Peel index. On the other hand, three were in grade 1 (M.O.H.) with Peel indices less than 8 , and had caused no clinical concern on admission. Six of the seven patients in this group had responded satisfactorily to the initial 50-mg. bolus of lignocaine, yet ventricular fibrillation supervened in three of them while still receiving a lignocaine infusion. Attempts to control recurrent ventricular fibrillation by increasing the infusion rate to 3 and $6 \mathrm{mg}$./minute failed in two patients.

Of the other three deaths one occurred in each of the postventricular fibrillation, recurrent atrial, and recurrent nodal ectopic groups.

\section{Discussion}

Sufficient evidence has now accumulated to show that lignocaine is a relatively effective and safe drug in the suppression of ventricular dysrhythmias after myocardial infarction (Lown et al., 1967 ; Jewitt et al., 1968 ; Spracklen et al., 1968). Our results confirm these findings. There is a strong presumption that the prophylactic use of the drug in patients with ventricular premature beats should lower mortality by reducing the incidence of ventricular fibrillation. There is, however, no statistical proof of this, and many physicians would hesitate to withhold the drug in order to carry out a controlled trial.

The use of lignocaine in coronary care units and in general medical wards requires the evaluation of a simple routine. For this reason we adhered to standard doses, both for the initial boluses and for the continuous infusion rates, without regard to the patient's weight. The work of Gianelly et al. (1967) and Jewitt et al. (1968), which included the measurement of lignocaine blood levels, indicated that $50 \mathrm{mg}$. would be an entirely safe initial bolus in any adult, and would also have a good chance of being effective. This proved to be the case, for suppression of ectopic beats by this dose was achieved in $57 \%$ of the 33 patients, and in no case were there any side-effects. A second bolus of $100 \mathrm{mg}$. achieved suppression of ectopic beats in a further $24 \%$ of patients and produced only minor side-effects in two. We therefore see no reason to modify this schedule, nor to alter the standard infusion rates of 1 and $2 \mathrm{mg}$. of lignocaine per minute. 
since the principal interest of this study relates to the prophylactic use of lignocaine in patients with ventricular ectopic beats after myocardial infarction, it is important to consider the circumstances of the seven deaths in this group of 33 patients (Table VII). Two died in ventricular fibrillation during the lignocaine infusion. Four others died at intervals between two and seven days after apparently successful lignocaine therapy. These patients were beyond the period of maximum risk of cardiac arrest (more than 72 hours after infarction), and no premonitory dysrhythmia was observed before the fatal one. The seventh patient did not respond to lignocaine therapy, and succumbed to ventricular fibrillation two hours later. This experience, despite the small numbers, has made us cautious in claiming that the use of this drug has significantly influenced the overall mortality. A double-blind trial of lignocaine therapy after myocardial infarction is now in progress.
We wish to acknowledge the collaboration of the medical and nursing staff of the cardiac monitoring unit.

REFERENCES

Aber, C P., Portal, R. W., and Chopra, M. P. (1969). Brit. med. f., 1, 209.

Carden, N. L., and Steinhaus, J. E. (1956). Circulat. Res., 4, 680.

Gianelly, R., Groeben, J. O., Spivack, A. P., and Harrison, D. C. (1967). New Engl. ₹. Med., 277, 1215

Harrison, D. C., Sprouse, J. H., and Morrow, A. G. (1963). Circulation, 28, 486 .

Jewitt, D. E., Kishon, Y., and Thomas, M. (1968). Lancet, 1, 266.

Likoff, W. (1959). Amer. F. Cardiol., 3, 427.

Lown, B., Fakhro, A. M., Hood, W. B., and Thorn, G. W. (1967). f. Amer. med. Ass., 199, 188.

Peel, A. A. F., Semple, T., Wang, I., Lancaster, W. M., and Dall, J. L. G. (1962). Brit. Heart F., 24, 745 .

Southworth, J. L., McKusick, V. A., Pierce, E. C., and Rawson, F. L.

(1950). \%. Amer. med. Ass., 143, 717.
Spracklen, F. H. N., Kimberling, J. J., Besterman, E. M. M., and Litchield, J. W.'(1968). Brit. med. Ұ̈., 1, 89.

World Health Organization (1959). Wld Hlth Org. techn. Rep. Ser., No. 168.

\title{
Positive Smear in Pregnancy
}

\author{
H. C. MCLAREN,* M.D., F.R.C.S., F.R.C.P.GLASG., F.R.C.O.G.
}

$S^{\min }$ ummary : Of 8,500 consecutive cervical cytology tests in the antenatal period a positive or suspect result was found in about $1 \%$. For the patients with a positive smear, examination under anaesthesia and small fourquadrant cervical biopsies are proposed as an alternative to antenatal conization, with its risk of subsequent haemorrhage or abortion.

A waiting policy is safe and permits normal delivery in hospital. Clinical and cytological follow-up is a vital part of conization-excision therapy. For the suspect smear (dyskaryosis) follow-up tests may revert to normal, but others may become positive and demand biopsy.

\section{Introduction}

In the management of a pregnant patient with a positive or suspect cytology test the obstetrician has the choice of observation with further tests from the cervix or some form of biopsy. Histology is, of course, the basis of diagnosis, but the pregnant cervix is soft and vascular and a cone biopsy carries the risk of haemorrhage or even abortion.

Since 1958 all antenatal patients have been screened in this unit, and we here describe the gradual evolution of a policy for clinical management. Over the period 1958 to 19658,500 consecutive antenatal patients were screened: 33 were positive $(3 / 1,000)$ and 81 suspect (dyskaryosis $(10 / 1,000)$. A positive test was an indication for four-quadrant biopsies around the cervical squamo-columnar junction to exclude invasive carcinoma as far as is possible.

\section{Intrapartum and Postnatal Care}

In four patients seen at an early stage of the investigation, intrapartum conization was attempted. The pathological reports of these were carcinoma-in-situ in one, basal cell dysplasia in two, and in one no abnormality.

* Professor of Obstetrics and Gynaecology, University of Birmingham.
Twenty conizations for positive tests were carried out on the postnatal and therefore relatively avascular cervix. The operation of conization not only aims at the diagnosis of cervical lesions but also aims to cure the patient, so that the conization as practised by this unit is extensive. The portio vaginalis cervicis and much of the cervical canal is included in what is in fact a cone-shaped partial amputation of the cervix. This, of course, is no outpatient procedure, since careful haemostasis is obligatory and often quite difficult to achieve (McLaren, 1967). Histological examination showed: carcinoma-in-situ in 14 , basal-cell dysplasia in five, and in one nothing abnormal was found.

Antenatal Care: Further Investigations.-Of the 33 patients with positive antenatal tests nine have not yet had a biopsy. The reasons for postponed biopsy can be summarized as follows: three became negative postnatally (under observation); one was lost to follow-up ; one was lost to follow-up for six years, then negative ; one postnatally negative, but became positive after six years; one postnatally negative, became positive after four years; one persisted postnatally as positive, but the patient declined further tests ; and one who refused treatment for three years developed fatal carcinoma of cervix.

\section{Positive Smear : Treatment Refused}

Case 1.-A para-12 aged 40, though she understood the risk, refused to have any form of biopsy despite repeated positive antenatal and postnatal tests. Three years later, still under observation, she developed cervical carcinoma, which rapidly extended out to the parametrium. Despite radiotherapy death occurred six months later.

Though not within this series a further two cases are here summarized.

Case 2.-A para-4 aged 44 had a positive smear in pregnancy in 1963. She declined biopsy but sent self-aspiration tests, which five years later were still positive.

Case 3.-A para-3 aged 45, from whose (clinically) normal cervix repeated positive smears were obtained, refused biopsy or treatment. Six years later she died of carcinoma of the cervix despite belated radiotherapy. 